\title{
Effects of Readily Fermentable Carbohydrate on Fiber Digestion by Rumen Microbes in Continuous Culture
}

\author{
Tsuneo Hino and Shinji Hamano \\ Department of Agriculture, Meiji University, \\ Tama-ku, Kawasaki-shi 214
}

(Received July 22, 1992)

\begin{abstract}
The effects of readily fermentable carbohydrate (RFC) on fiber digestion were examined by continuous culture conducted at $\mathrm{pH} 6.7$ for $5 \mathrm{~d}$ during which the main rumen microbes were maintained. The addition of a low level of corn starch to a basal diet consisting of hay powder and concentrate increased the digestibility of neutral detergent fiber. This suggests that moderate levels of RFC enhance the overall utilization of fiber, possibly because fibrolytic microbes increase by utilizing RFC and fibrolysis is increased by the increased fibrolytics after RFC is exhausted. However, a high level of corn starch decreased fiber digestion, and continuous infusion of the same amount of glucose further depressed fibrolysis. A similar trend was observed when glucose was continuously infused into the culture of bacteria fed ball-milled cellulose. Indirect estimation suggested that the number of cellulolytic bacteria was larger with $8 \mathrm{~g} / \mathrm{l}$ than $2 \mathrm{~g} / \mathrm{l}$ of soluble starch, infused continuously. Therefore, it is possible that the depression of cellulose digestion by high levels of RFC was not due to the decreased number of cellulolytics, but due to the suppression of fibrolytic activity in cellulolytics. Cellulolytic bacteria may preferentially utilize sugers. Thus, the utilization of fiber is apparently affected by RFC in two opposite directions, depending on the level of RFC.

Anim. Sci. Technol. (Jpn.) 64 (11) : 1070-1078, 1993
\end{abstract}

Key words : rumen microbes, fiber digestion, readily fermentable carbohydrate

Plant fiber is the most abundant organic resource that is renewable. As pointed out by ChAmpion et al. ${ }^{31}$, the current practice of feeding high concontrate diets to cattle is a luxury that future generations may not experience, and enhanced cellulose utilization will be increasingly important. Therefore, it is particularly important to explore methods and conditions to both maximize fiber utilization and minimize the use of concentrate diets.

As reported previously ${ }^{11}$, we proved, by using rumen-simulating continuous culture, that feeding high levels of concentrate depresses fiber digestion by rumen microbes.
The major reason for this is the drop in $\mathrm{pH}$ principally because cellulolytic bacteria are particularly sensitve to low $\mathrm{pH}^{12,18,19,22,23)}$. When the $\mathrm{pH}$ value was kept at 6.7 , the addition of a moderate level of concentrate enhanced the digestion of neutral detergent fiber $(\mathrm{NDF})^{11)}$. Probably, this indicates that the intermediate products of starch digestion, such as glucose and maltose, enhance the growth rate of fibrolytic microbes, and that NDF digestion is increased by the increased fibrolytic microbes after the readily fermentable carbohydrate (RFC) is exhausted.

However, a higher level of concentrate de- 
pressed NDF digestion, even when $\mathrm{pH}$ was kept at 6.7. As discussed in our previous paper ${ }^{11}$, the presence of $\mathrm{RFC}$ for a prolonged time may shorten the period of fiber utilization, resulting in the depression of overall fiber utilization. There appears to be a preferential use of substrates in fibrolytic microbes, which is referred to as "the carbohydrate effect" ${ }^{12}$.

Thus, RFC may affect the utilization of fiber in two opposite directions, depending on the length of time for which RFC is available. If so, it is very important to feed appropriate levels of RFC in order to maximize fiber utilization. Feeding balanced nutrients, especially nitrogen sources, is also needed for the efficient utilization of fiber ${ }^{12,13}$.

The objectives of our study were to verify that the effects of concentrate observed previously and described above are due to RFC, and to examine the effects of RFC on overall fiber digestion by mixed populations of rumen microbes maintained in a continuous culture during which the $\mathrm{pH}$ value is kept at 6.7. Our chief concern was to gain evidence for the carbohydrate effect, i.e., the direct suppression of fiber utilization by RFC.

\section{Materials and Methods}

Apparatus: Our continuous culture apparatus was functionally the same as that described previously ${ }^{11}$, except that the dialyzing system was omitted. Preliminary experiments suggested that similar microbes are maintained without dialysis for a short term ( $5 \mathrm{~d})$, unless too much feed is given, and if the $\mathrm{pH}$ is controlled. As shown in Fig. 1-A, a water bath (f) was used in the present study. Fermenter vessels were smaller than before, i.e.,
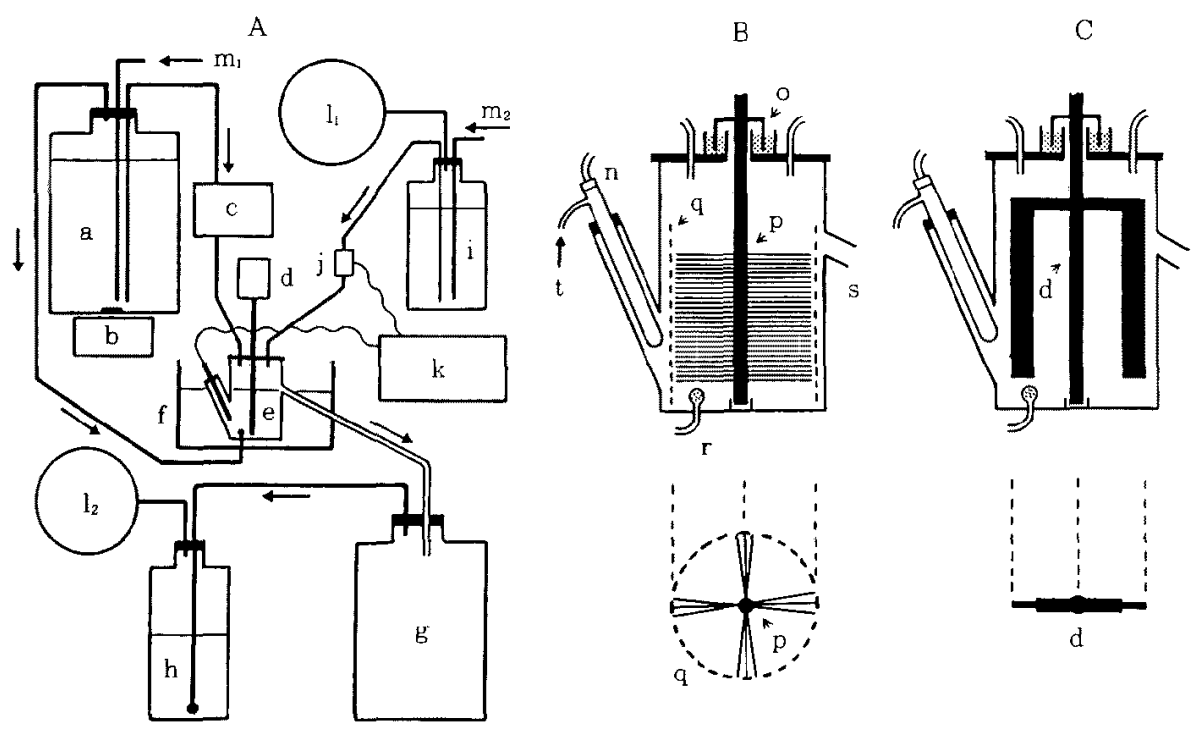

Fig. 1. Continuous culture apparatus:

A. whole apparatus, B. fermenter vessel A, C. fermenter vessel B.

a. reservoir for a saline or medium solution, b. magnetic stirrer, c. peristaltic pump, d. agitator,

e. fermenter, f. incubator (water bath), $g$. bottle for the overflow (effluent from the fermenter),

h. $10 \% \mathrm{KOH}$ to absorb $\mathrm{CO}_{2}$, i. $2 \% \mathrm{Na}_{2} \mathrm{CO}_{3}$ to adjust pH, j. electromagnetic valve, $\mathrm{K}$. pH regulator,

1. gas bag $\left(\mathrm{l}_{1}, \mathrm{~N}_{2} ; \mathrm{L}_{2}, \mathrm{CH}_{4}\right), \mathrm{m}$. inlet for gas $\left(\mathrm{m}_{1}, \mathrm{CO}_{2} ; \mathrm{m}_{2}, \mathrm{~N}_{2}\right)$, n. pH electrode, o. mercury for sealing, p. agitator with brushes, q. stainless-steel mesh cylinder $\left(22\right.$ mesh), r. inlet for $\mathrm{CO}_{2}$ (ball-shaped glass filter), s. overflow port, $t$. inlet for air to pressurize. 
two kinds of fermenters having a capacity of $300 \mathrm{~m} l$ (up to the overflow) were used: One (Fig. 1-B, vessel $A$ ) had a sieve (q) and brushes (p), and the other (Fig. 1-C, vessel B) had only an agitator (d). The apparatus was equipped with a $\mathrm{pH}$ regulator $(\mathrm{k})$ connected to an electromagnetic valve (j), and a device for collecting methane $\left(h, l_{2}\right)$. Four sets of the apparatus were used in parallel. Further details have been described in a previous paper $^{11}$.

Operation and culture conditions: Operation of the continuous culture apparatus and culture conditions were basically the same as those previously described ${ }^{(1)}$.

As a source of mixed rumen microbes, rumen fluid prepared by squeezing rumen contents through two layers of surgical gauze was used. The rumen contents were harvested from a goat fed as described previously ${ }^{10)}$. Mixed rumen bacteria were prepared by removing protozoa from the mixed rumen microbes ${ }^{7,10 \text { ) }}$.

The mixed rumen microbes were introduced into the fermenters (vessel A), and a buffered saline solution was pumped continuously into the fermenters. The saline solution was composed of $(\mathrm{g} / \mathrm{l}): \mathrm{KH}_{2} \mathrm{PO}_{4}, 4.0 ; \mathrm{Na}_{2} \mathrm{HPO}_{4}$. $12 \mathrm{H}_{2} \mathrm{O}, 12.0 ; \mathrm{NaCl}, 1.0 ; \mathrm{MgSO}_{4} \cdot 7 \mathrm{H}_{2} \mathrm{O}, 0.1$; $\mathrm{CaCl}_{2} \cdot 2 \mathrm{H}_{2} \mathrm{O}, 0.1$; urea, 1.0 ; and cysteine$\mathrm{HCl}, 0.6$. The $\mathrm{pH}$ value was adjusted to 6.7 with $\mathrm{Na}_{2} \mathrm{CO}_{3}$ under $\mathrm{CO}_{2}$. As a basal diet, hay powder and commercial concentrate ${ }^{11)}$ (each $3 \mathrm{~g} / \mathrm{d}$ ) were used. The hay powder was prepared from timothy hay and alfalfa haycubes (1:1) by coarse gringing with an electric mill ${ }^{11}$. The composition of the basal diet is shown in Table 1. The basal diet, corn starch particles, and/or casein powder were fed twice dialy (every $12 \mathrm{~h}$ ) after $\mathrm{O}_{2}$ was removed ${ }^{11)}$, and glucose and/or Trypticase (BBL) were continuously infused with the saline solution. To maintain protozoa, clover juice $(4 \mathrm{ml} / \mathrm{d})$ was added every time solid feed was given ${ }^{8,11}$.

In order to estimate the growth yield of bacteria and the numbers of cellulolytic
Table 1. Composition of the basal diet

\begin{tabular}{lccc}
\hline Component & $\begin{array}{c}\text { Hay } \\
\text { powder*1 } \\
(\%)\end{array}$ & $\begin{array}{c}\text { Concen- } \\
\text { trate } \\
(\%)\end{array}$ & $\begin{array}{c}\text { Basal } \\
\text { diet }^{* 2} \\
(\%)\end{array}$ \\
\hline Moisture & 11.3 & 9.2 & 10.3 \\
NDF & 43.7 & 12.1 & 27.9 \\
Crude protein & 12.1 & 15.7 & 13.9 \\
Crude fat & 2.3 & 1.9 & 2.1 \\
Ash & 8.7 & 9.3 & 9.0 \\
NFE & 21.9 & 51.8 & 36.9 \\
\hline
\end{tabular}

*1 : Timothy hay + alfalfa haycubes $(1: 1)$

*2: Hay powder + Concentrate $(1: 1)$

bacteria, mixed rumen bacteria were grown in vessel $B$ by continuous infusion of the following growth medium; ball-milled cellulose, 1.0 $\mathrm{g}$; Trypticase, $2.0 \mathrm{~g}$; yeast extract, $1.0 \mathrm{~g}$; varied amounts of glucose or soluble starch; cysteine- $\mathrm{HCl}, \quad 0.6 \mathrm{~g} ; \quad \mathrm{MgSO}_{4} \cdot 7 \mathrm{H}_{2} \mathrm{O}, 0.2 \mathrm{~g}$; $\mathrm{CaCl}_{2} \cdot 2 \mathrm{H}_{2} \mathrm{O}, 0.2 \mathrm{~g}$; clarified rumen fluid, 300 $\mathrm{ml}$; and the buffered saline solution described above, $700 \mathrm{ml}$. Ball-milled cellulose was prepared by grinding cellulose powder (Toyo Roshi Co. Ltd.) with a ball mill for $24 \mathrm{~h}$. Clarified rumen fluid was prepared by centrifugation $(12,000 \times \mathrm{g}, 15 \mathrm{~min})$ of the rumen fluid described above.

Continuous culture was performed at $39^{\circ} \mathrm{C}$ and $\mathrm{pH} 6.7$ for $5 \mathrm{~d}^{11)}$, with the same experiment repeated three times. Unless otherwise indicated, the dilution rate (D) was set at $1.5 / \mathrm{d}$.

Analyses: NDF was determined according to the method of VAN SOEST and WINE ${ }^{24)}$, and volatile fatty acids (VFA) were analyzed by GLC as described previously ${ }^{5)}$. Ammonia was collected by the microdiffusion $\operatorname{method}^{2)}$ and assayed by the indophenol method ${ }^{1)}$. Samples for VFA and ammonia were taken from the overflow on the 3 rd and 5 th day. There was little deviation between days. Methane was determined by $\mathrm{GLC}^{5)}$ using $\mathrm{H}_{2}$ as an internal standard $^{11)}$. Protozoa were counted as described preciously ${ }^{7)}$ after $5 \mathrm{~d}$, when the culture was terminated.

The amount of bacterial cells was estimated 
from bacteria-nitrogen (N) as follows: Aliquots of the overflow were centrifuged $(12,000 \times \mathrm{g}, 15 \mathrm{~min})$ and the pellets were determined for $\mathrm{N}$ by the Kjeldahl method ${ }^{10}$. The pellet- $N$ was regarded as bacteria- $N$, because the culture medium did not contain precipitable $\mathrm{N}$. The dry matter (DM) of bacteria was calculated using the value of $11.2 \% \mathrm{~N}$ in DM, which had been obtained for mixed rumen bacteria. Growth yield was expressed as $\mathrm{Y}_{\text {glucose }}$ (bacteria-DM/mol glucose utilized), where glucose includes cellulose expressed as the glucose unit. Glucose was not detected by $\mathrm{TLC}^{9,15)}$ in any overflow, indicating that virtually all the glucose infused was utilized. Cellulose utilization was estimated via the same method as for determining NDF, as described previously ${ }^{6}$.

The numbers of cellulolytic bacteria remaining after $5 \mathrm{~d}$ of continuous culture were estimated by cellulose digestion in short-term culture as follows: Mixed rumen bacteria were grown by continuous culture in a growth medium containing $1 \mathrm{~g} / \mathrm{l}$ of ball-milled cellulose and 2 or $8 \mathrm{~g} / l$ of soluble starch. After $5 \mathrm{~d}$, a half volume of each culture was withdrawn to determine the amount of cellulose, and an equal volume of fresh medium containing $2 \mathrm{~g} / \mathrm{l}$ of ball-milled cellulose (without starch) was added. The cultures were incubated for an additional $12 \mathrm{~h}$ without infusion of the culture medium, i.e., a closed system, and the remaining cellulose was determined.

Data were evaluated by the Tukey's test ${ }^{21}$.

\section{Results and Discussion}

Effects of corn starch and glucose on fiber digestion by mixed rumen microbes in a continuous culture: The addition of $1.5 \mathrm{~g} / \mathrm{d}$ of corn starch particles to the basal diet $(6 \mathrm{~g} / \mathrm{d})$, given twice daily, significantly increased NDF digestion (Table 2), thus validating our previous inference that the enhancement of NDF digestion by a moderately increased concentrate is mainly due to increased starch ${ }^{11}$. To a lesser extent, the increased level of protein also may have increased fiber digestion in the previous experiments, although the enhancement of NDF digestion by casein was statistically insignificant in the present experiment.

Table 2. Effects of corn starch given twice daily and glucose continuously infuscd on NDF digestion, methane production, and protozoal number in the continuous culture of mixed rumen microbes*1

\begin{tabular}{|c|c|c|c|c|c|c|}
\hline \multicolumn{2}{|c|}{ Carbohydrate $(\mathrm{g} / \mathrm{d})$} & \multicolumn{2}{|c|}{ Amino acid source $(\mathrm{g} / \mathrm{d})$} & \multicolumn{3}{|c|}{ Relative value $(\%)$ of } \\
\hline Starch*2 & Glucose $^{* 3}$ & Casein $^{* 2}$ & Trypticase $^{* 3}$ & $\begin{array}{l}\text { Digestibility } \\
\text { of } \mathrm{NDF}^{* 4}\end{array}$ & $\begin{array}{l}\text { Methane } \\
\text { production*5 }\end{array}$ & $\begin{array}{l}\text { Final number } \\
\text { of protozoa }\end{array}$ \\
\hline 0 & 0 & 0 & 0 & $100 \pm 2^{c}$ & $100 \pm 2^{\mathrm{a}}$ & $100 \pm 4^{a}$ \\
\hline 1.5 & 0 & 0 & 0 & $131 \pm 3^{d}$ & $131 \pm 3^{b}$ & $162 \pm 6^{b}$ \\
\hline 1.5 & 0 & 0.3 & 0 & $144 \pm 4^{d}$ & $136 \pm 3^{b}$ & $183 \pm 5^{b c}$ \\
\hline 1.5 & 0 & 0.6 & 0 & $139 \pm 2^{d}$ & $125 \pm 2^{b}$ & $176 \pm 7^{b c}$ \\
\hline 0 & 0 & 1 & 1 & $104 \pm 3^{c}$ & $108 \pm 2^{a}$ & $105 \pm 5^{*}$ \\
\hline 5 & 0 & 1 & 1 & $81 \pm 4^{b}$ & $168 \pm 3^{\mathrm{cd}}$ & $190 \pm 6^{\circ}$ \\
\hline 2.5 & 2.5 & 1. & 1 & $68 \pm 3^{\mathrm{ab}}$ & $162 \pm 2^{c}$ & $173 \pm 8^{b c}$ \\
\hline 0 & 5 & 0 & 2 & $59 \pm 3^{a}$ & $179 \pm 3^{d}$ & $87 \pm 5^{a}$ \\
\hline
\end{tabular}

*: Data are standardized for triplicate experiments (equalizing the control values), and expressed as $\%$ of the control values (mean $\pm S E, n=3$ ). Figures with different superscripts differ from each other $(P<0.05)$.

${ }^{*}$ : Given twice daily.

${ }^{* 3}$ : Continuously infused. *4 : Decrease/input (control value, $63 \%$ ).

${ }^{*}$ : Total methane in $5 \mathrm{~d}$ (control value, $28.9 \mathrm{mmol} / \mathrm{culture}$ ).

${ }^{*}$ : Remaining protozoa after $5 \mathrm{~d}$ (control value, $7.5 \times 10^{4} / \mathrm{ml}$ ). 


\section{Hino and Hamano}

Generally, a sufficient supply of amino acids stimulates the growth of fibrolytic bacteria ${ }^{12}$, and an adequate supply of ammonia and branched-chain VFA is also needed for the efficient growth of cellulolytic bacteria ${ }^{12)}$. The concentrations of ammonia and branched-chain VFA were increased by adding casein (Fig. 2), but it is unclear whether increased levels of these substances enhanced fiber digestion. As discussed in our previous paper ${ }^{11}$, ammonia levels above $5 \mathrm{mM}$ and the supply of branchedchain VFA without cessation may be enough for the growth of cellulolytic bacteria.

When $5 \mathrm{~g} / \mathrm{d}$ of corn starch were given twice daily, the digesibility of NDF decreased signif-

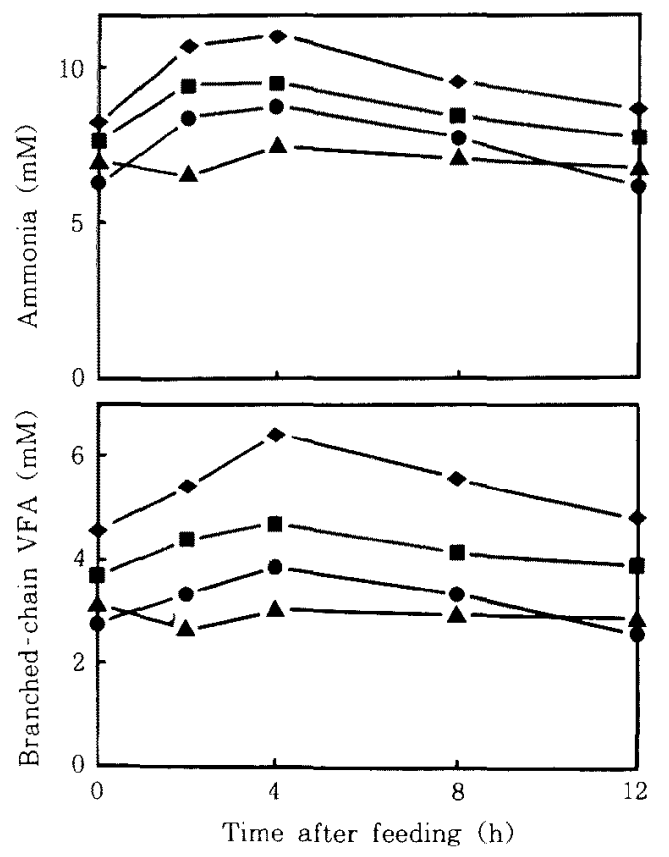

Fig. 2. Concentrations of ammonia and branched-chain VFA in the continuous culture of mixed rumen microbes: Samples were taken on the 3 rd and 5 th day, and the mean values are shown.

- basal diet (control), $\boldsymbol{\Lambda}:+1.5 \mathrm{~g} / \mathrm{d}$ corn starch, $\mathbf{D}$ : $+1.5 \mathrm{~g} / \mathrm{d}$ corn starch $+0.3 \mathrm{~g} / \mathrm{d}$ casein, : $+1.5 \mathrm{~g} / \mathrm{d}$ corn starch $+0.6 \mathrm{~g} / \mathrm{d}$ casein icantly (Table 2). The continuous infusion of $5 \mathrm{~g} / \mathrm{d}$ of glucose depressed fiber digestion to a significantly greater degree compared with $5 \mathrm{~g} / \mathrm{d}$ of starch. A combination of $2.5 \mathrm{~g} / \mathrm{d}$ of starch (fed twice daily) and glucose (continuously infused) gave an intermediate value. The concentration of total VFA was hihger when starch and/or glucose were added (Fig. 3), but it is unlikely that these levels of VFA inhibit the activity or growth of fibrolytic microbes ${ }^{17)}$. The supply of amino acids $(2 \mathrm{~g} / \mathrm{d}$, with $5 \mathrm{~g} / \mathrm{d}$ of carbohydrate) must have been sufficient, because there was no difference in NDF digestion between 0.3 and $0.6 \mathrm{~g} / \mathrm{d}$ of casein in the

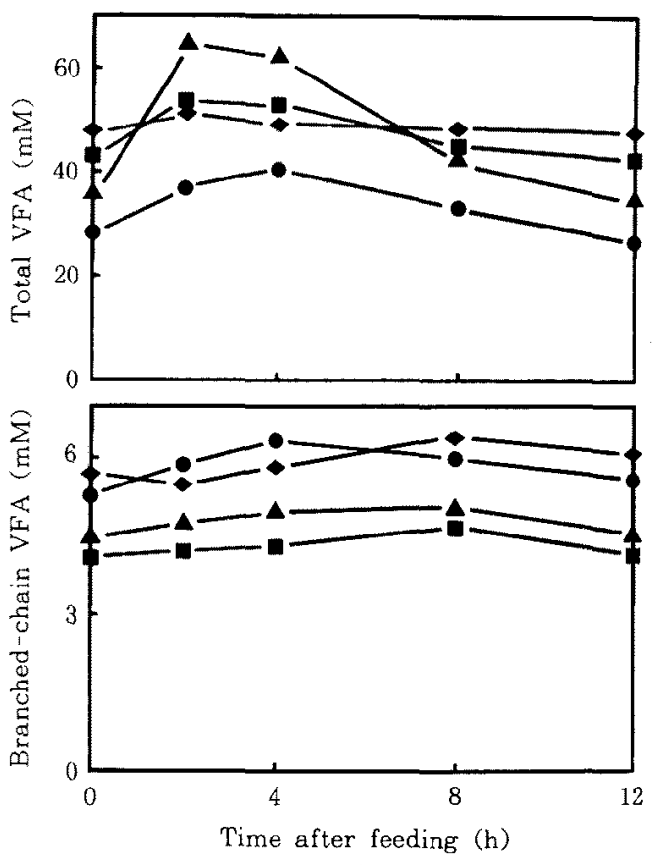

Fig. 3. Concentrations of total and branched-chain VEA in the continuous culture of mixed rumen microbes: Data on the 5th day are shown.

- basal diet $+1 \mathrm{~g} / \mathrm{d}$ casein $+1 \mathrm{~g} / \mathrm{d}$ Trypticase, $\mathbf{\Delta}:+5 \mathrm{~g} / \mathrm{d}$ corn starch, $\mathbf{\Sigma}:+2.5 \mathrm{~g} / \mathrm{d}$ corn starch $+2.5 \mathrm{~g} / \mathrm{d}$ glucose, $\quad+5 \mathrm{~g} / \mathrm{d}$ glucose $(+2 \mathrm{~g} / \mathrm{d}$ Trypticase instead of $1 \mathrm{~g} / \mathrm{d}$ each of casein and Trypticase). For details see Table 1 . 
case of $1.5 \mathrm{~g} / \mathrm{d}$ of starch (Table 2). The levels of branched-chain VFA (Fig. 3) and ammonia (6-12 $\mathrm{mM})$ were within normal ranges ${ }^{12}$. Methane production and protozoal number were increased by starch and glucose, except that the supply of glucose alone did not increase protozoa (Table 2). These results may exclude the possibility that the environmental conditions were unfavorable to celluloytic bacteria.

Therefore, it could be concluded that the presence of $\mathrm{RFC}$ for a long time suppresses fiber utilization; i.e., there appears to be a carbohydrate effect. As speculated previously ${ }^{11}$, when a moderate amount of starch is supplied $(1.5 \mathrm{~g} / \mathrm{d}$ in the present experiment), fibrolytic microbes may increase by utilizing the intermediate products of starch digestion. After RFC is exhausted, fiber digestion may increase due to the increased fibrolytic $\mathrm{mi}$ crobes: This may result in increased overall utilization of fiber, if $\mathrm{pH}$ value is kept near neutral. It is also possible that an adequate supply of starch increases non-fibrolytic microbes, which may have some favorable effects of fibrolytic microbes.

However, when the amount of starch is high ( $5 \mathrm{~g} / \mathrm{d}$ in the present experiment), starch and its intermediate products are present for a longer time, which shortens the period for fiber digestion. This explanation is compatible with the obtained result that the continuous infusion of glucose greatly depresses fiber digestion (Table 2).

Effects of continuous infusion of glucose on cellulose digestion and growth yield in the continuous culture of mixed rumen bacteria: As shown in Table 3 , when D was low $(1.0 / d)$, the continuous infusion of $2 \mathrm{~g} / \mathrm{l}(0.6 \mathrm{~g} / \mathrm{d})$ of glucose significantly increased the digestibility of cellulose, whereas 4 and $8 \mathrm{~g} / l(1.2$ and $2.4 \mathrm{~g} / \mathrm{d}$ ) of glucose depressed cellulose digestion. In the case of high $\mathrm{D}(2.0 / \mathrm{d}), 2 \mathrm{~g} / \mathrm{l}$ of glucose did not significantly increase cellulose digestion. This difference is probably due to the increased utilization of glucose at high D, because glucose supply per unit time was doubled. At 4 and $8 \mathrm{~g} / l$ of glucose, cellulose digestion greatly decreased. The lower digestibility of cellulose at high $\mathrm{D}$ is possibly due to the shorter retention time of cellulose. It is unlikely that the levels of ammonia and branched-chain VFA limited the growth of cellulolytic bacteria in any case (Table 3 ). These results suggest again that a moderate supply of RFC enhances cellulose digestion, but the presence of RFC above a certain level has an adverse effect on cellulolysis. Cellulose was digested even when $8 \mathrm{~g} / l$ of glucose were infused, suggesting that the effects of RFC do

Table 3. Effects of continuously infused glucose on cellulose digestion and $\mathrm{Y}_{\text {glucose }}$ in the continuous culture of mixed rumen bacteria

\begin{tabular}{cccccc}
\hline $\begin{array}{c}D \\
\text { /d) }\end{array}$ & $\begin{array}{c}\text { Glucose } \\
(\mathrm{g} / l)\end{array}$ & $\begin{array}{c}\text { Digestibility of } \\
\text { cellulose }(\%)\end{array}$ & $Y_{\text {glucose }}$ & $\begin{array}{c}\text { Ammonia } \\
(\mathrm{mM})\end{array}$ & $\begin{array}{c}\text { Branched-chain } \\
\text { VFA (mM) }\end{array}$ \\
\hline 1.0 & 0 & $48 \pm 1^{\mathrm{e}}$ & $26 \pm 1^{\mathrm{d}}$ & $9.8 \pm 0.2^{\text {cd }}$ & $5.3 \pm 0.2^{\mathrm{cd}}$ \\
& 2 & $57 \pm 2^{\mathrm{f}}$ & $33 \pm 1^{\mathrm{b}}$ & $10.2 \pm 0.3^{\text {cd }}$ & $5.0 \pm 0.1^{\mathrm{c}}$ \\
& 4 & $40 \pm 2^{\mathrm{d}}$ & $37 \pm 1^{\mathrm{bc}}$ & $8.3 \pm 0.3^{\mathrm{ab}}$ & $4.5 \pm 0.1^{\mathrm{ab}}$ \\
& 8 & $30 \pm 2^{\mathrm{bc}}$ & $39 \pm 1^{\mathrm{cd}}$ & $7.5 \pm 0.2^{\mathrm{a}}$ & $4.1 \pm 0.1^{\mathrm{a}}$ \\
2.0 & 0 & $35 \pm 1^{\mathrm{cd}}$ & $25 \pm 0^{\mathrm{a}}$ & $12.9 \pm 0.4^{\mathrm{e}}$ & $6.2 \pm 0.2^{\mathrm{c}}$ \\
& 2 & $38 \pm 2^{\mathrm{cd}}$ & $38 \pm 1^{\mathrm{c}}$ & $11.2 \pm 0.2^{\mathrm{de}}$ & $6.1 \pm 0.2^{\mathrm{de}}$ \\
& 4 & $25 \pm 2^{\mathrm{b}}$ & $43 \pm 1^{\mathrm{de}}$ & $9.5 \pm 0.2^{\mathrm{c}}$ & $6.4 \pm 0.1^{\mathrm{e}}$ \\
& 8 & $17 \pm 1^{\mathrm{a}}$ & $45 \pm 2^{\mathrm{e}}$ & $9.2 \pm 0.3^{\mathrm{bc}}$ & $4.8 \pm 0.1^{\mathrm{bc}}$ \\
\hline
\end{tabular}

For explanations see the text and the footnote of Table 1 . 
not follow the all or nothing law, and/or that the cellulolytic activity of some species of bacteria is not affected by RFC.

Growth yield ( $\left.\mathrm{Y}_{\text {glucose }}\right)$ was increased by glucose, indicating that glucose is utilized for growth with an energetically higher efficiency than cellulose (Table 3). Increased $\mathrm{Y}_{\text {glucose }}$ with the increased supply of glucose suggests the enhanced growth of non-cellulolytic bacteria, but the cellulolytic bacteria may also have grown with higher efficiency when glucose was given (see below). When glucose was supplied, $\mathrm{Y}_{\mathrm{glucose}}$ was higher at high $\mathrm{D}$ than low $\mathrm{D}$, obviously indicating that the growth rate increased due to the increased rate of glucose supply. On the other hand, when cellulose alone was supplied, $\mathrm{Y}_{\mathrm{g} \text { lucose }}$ was not increased by the increased $D$, indicating that the growth rate of cellulolytic bacteria was not enhanced by the raised rate of cellulose supply. It is evident from the incomplete utilization of cellulose ( $c f$. , digestibility was far below $100 \%$ ) that the growth rate of celluloytic bacteria was limited by the rate of cellulolysis, not by the infusion rate of cellulose. In other words, the energetic efficiency of the growth of cellulolytic bacteria on cellulose greatly depends on the rate of cellulose degradation.

Effects of the level of soluble starch on the amount of cellulolytic bacteria in a continuous culture: As shown in Table 4, cellulose digestion over the $5 \mathrm{~d}$ of the continuous culture of mixed bacteria was significantly decreased by raising the level of soluble starch from 2 to $8 \mathrm{~g} / \mathrm{l}$. This result is essentially the same as that of the preceding experiment. When the cultures were incubated after $5 \mathrm{~d}$ with ballmilled cellulose (without starch) for an addi. tional $12 \mathrm{~h}$, cellulose digestion was significantly higher in the cultures that were precultured with $8 \mathrm{~g} / l$ than $2 \mathrm{~g} / l$ of soluble starch. Because cellulolytic bacteria do not grow rapidly on cellulose, cellulose digestion in the subsequent $12 \mathrm{~h}$ probably reflects the initial numbers of cellulolytic bacteria. Therefore, it is possible
Table 4. Cellulose digestion by the mixed bacteria remaining after $5 \mathrm{~d}$ of continuous culture with a high or low level of soluble starch infused continuously*

\begin{tabular}{ccc}
\hline $\begin{array}{c}\text { Soluble } \\
\text { starch } \\
(\mathrm{g} / l)\end{array}$ & \multicolumn{2}{c}{ Digestibility of cellulose $(\%)$} \\
\cline { 2 - 3 } & $5 \mathrm{~d}$ & $12 \mathrm{~h}$ after $5 \mathrm{~d}$ \\
\hline 2 & $51 \pm 2^{\mathrm{b}}$ & $32 \pm 1^{\mathrm{a}}$ \\
8 & $36 \pm 1^{\mathrm{a}}$ & $39 \pm 2^{\mathrm{b}}$ \\
\hline
\end{tabular}

*: Detaiis are given in the text.

that the number of cellulolytic bacteria present after $5 \mathrm{~d}$ of preculture was larger when the higher level of starch was infused.

These results suggest that the decrease in cellulose digestion at a high level of starch was not caused by the decrease in number of cellulolytic bacteria. Presumably, the presence of RFC above a certain level directly suppresses cellulose digestion. This may be caused by the preferential utilization of RFC by cellulolytics.

MORRISON et al. ${ }^{16)}$ reported that cellulolysis by an anaerobic ruminal fungus was catabolite regulated by glucose, cellobiose, and soluble starch, but we did not check the presence of fungi in this study. Even though fungi were present, the effects of RFC observed in our study may lergely be attributable to the actions on cellulolytic bacteria. The carbohydrate effects have been shown for cellulolytic rumen bacteria ${ }^{4,11,14,20)}$, but whether these bacteria are subject to catabolite repression remains to be examined.

This study was supported in a part by a Grant-in-Aid (Bio-Cosmos Program) from the Ministry of Agriculture, Forestry, and Fisheries (BCP-92-II-B-1).

\section{References}

1) Chaney, A.L. and E.P. Marbach, Modified reagents for determination of urea and ammonia. Clin. Chem, , $8:$ 130-132. 1962.

2) Conway, E.J. and A. Byrne, An absorption apparatus for the micro-determination of certain volatile substances: I. The 
micro-determination of ammonia. Biochem. J., $27: 419-429.1933$.

3) Champion, K.M., C.T. Helaszek, and B. $\Lambda$. White, Analysis of antibiotic susceptibility and extrachromosomal DNA content of Ruminococcus albus and Ruminococcus flavefaciens. Can. J. Microbiol., 34 : 11091115. 1988.

4) Fusee, M.C. and J.M. LEATHERwoOd, Regulation of cellulase from Ruminococcus. Can. J. Microbiol, 18: 347-353. 1972.

5) Hino, T., Action of monensin on rumen protozoa. Jpn. J. Zootech. Sci,, 53 : 171179. 1981

6) Hino, T., N. AndoH and H. OHGI, Effects of $\beta$-carotene and $\alpha$-tocopherol on utilization of long-chain fatty acids and cellulose digestion by mixed rumen bacteria in vitro. J. Dairy Sci., 76 : 600-605. 1993.

7) Hino, T., M. Kametaka and M. Kandatsu, The cultivation of rumen oligotrich protozoa: I. Factors influencing the life of entodinia. J. Gen. Appl. Microbiol., 19: 305-315. 1973.

8) Hino, T., M. Kametaka, and M. Kandatsu, The cultivation of rumen oligotrich protozoa: III. White clover factors which stimulate the growth of entodinia. J. Gen. Appl. Microbiol., 19: 397-413. 1973.

9) Hino, T., K. MiyazakA, and S. Kuroda, Role of extracellular acetate in the fermentation of glucose by a ruminal bacterium, Megasphaera elsdenii. J. Gen. Appl. Microbial., 37 : 121-129. 1991.

10) Hino, T., K. Miyazaki, S. Kuroda and T. GoToH, Effect of ethanol on the degradation of protein and amino acids by rumen microorganisms. Anim. Sci. Technol. (Jpn.), 63: 173-179. 1992

11) Hino, T., M. Sugiyama and K. Okumura, Maintenance of protozoa and methanogens, and fiber digestion in rumen-simulating continuous culture. J. Gen. Appl. Microbiol., 39: 35-45. 1993.

12) Hoover, W.H., Chemical factors involved in fiber digestion. J. Dairy Sci., 69 : 27552766. 1986.

13) Hoover, W.H. and S.R. STokes, Balancing carbohydrates and proteins for optimum rumen microbial yield. J. Dairy Sci., 74 : 3630-3644. 1991.
14) Huang, L. and C.W. Forsberg, Cellulose digestion and distribution in Fibrobacter succinogenes subsp. succinogenes $\$ 85$. Appl. Environ. Microbiol., 56 : 1221-1228. 1990.

15) Lewis, B.A. and F. SMITH, Thin-Layer Chromatography, A Laboratory Handbook. 2nd ed. (STAHL, E., ed.) 813-815. Springer-Verlag. Brelin and New York. 1969.

16) Morrison, M., R.I. MAckin, and A. Kistner, Evidence that cellulolysis by an anaerobic ruminal fungus is catabolite regulated by glucose, cellobiose, and soluble starch. Appl. Environ. Miocrobiol., 56: 3227-3229. 1990.

17) PRINS, R.A. and R.T.J. Clarke, Microbial ecology of the rumen, in Digestive Physiology and Metabolism in Ruminants. (Ruckebusch, $Y$. and $P$. Thivend, eds.) 179-204. MTP Press. Lancaster. 1980.

18) Russelu, J.B., Effect of extracellular pH on growth and proton-motive force of Bacteroides succinogenes, a cellulolytic ruminal bacterium. Appl. Environ. Microbiol., 53 : 2379-2383. 1987.

19) Russell, J.B. and D.B. Dombrowski, Effect of $\mathrm{pH}$ on the efficiency of growth by pure cultures of rumen bacteria in continuous culture. Appl. Environ. Mierobiol., $39: 604-610.1980$.

20) Smith, W.R., I. Yu, and R.E. Hungate, Factors affecting cellulolysis by Ruminococcus albus. J. Bacteriol., 114: $729-737$. 1973.

21) Snedecor, G.W. and W.G. Cochran, Statistical Methods, 5nd ed. lowa State University Press. Ames. 1967.

22) Stewart, C.S., Factors affecting the cellulolytic activity of rumen contents. Appl. Environ. Microbiol. 33: 497-502. 1977.

23) Terry, R.A., M.A. Tilly, and G.E. OUTEN, Effect of $\mathrm{pH}$ on cellulose digestion under in vitro conditions. J. Sci. Food Agric., 20 317-320. 1969.

24) Van Soest, P.J. and P.H. WINe, Use of detergents in the analysis of fibrous feeds. IV. Determination of plant cell-wall constituents. J. Assoc. Off. Anal. Chem., $50: 50-55.1967$. 


\title{
連続培養におけるルーメン微生物による繊維の 消化に及ぼす易発酵性炭水化物の影響
}

\author{
日野常男・浜野真司 \\ 明治大学農学部, 川崎市 214
}

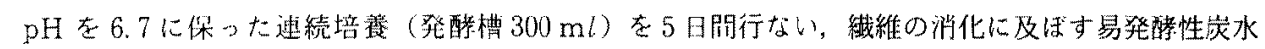

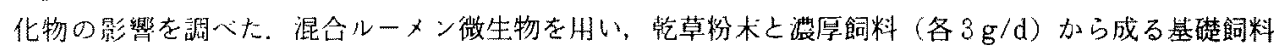
を一日 2 囘給与した対照区と比較し，基礎飼料に $1.5 \mathrm{~g} / \mathrm{d} の$ とうもろこしデンプンを添加した場合に は，山性デタージェント䋐維の消化㳯が增加したが， $5 \mathrm{~g} / \mathrm{d}$ のデンプンを添加した場合には，娍少した。 $5 \mathrm{~g} / \mathrm{d} の$ ダルコースを連続注入したよころ, 馀維の消化は更に低下した，増殖培地にボールミル・セル ロース在添加した培養液を連続注入して混合ルーメンバクテリアを培養し，この培養液に種々の濃度の グルコースを添加した場合の影響を調べたところ, 低濃度 $(2 \mathrm{~g} /$ / )のグルコースではセルロースの分

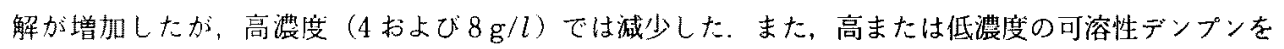

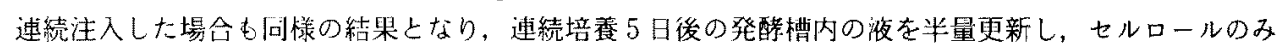

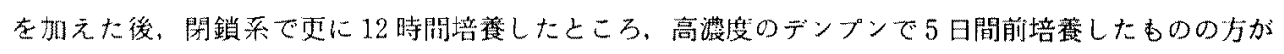
セルロース分解が大きく, 前培養後のセルロース分解菌の量が多かったよ推測された，従って，高レベ ルのデンプンでセルロース消化が低下するのはセルロース分解菌の威少によるおのではなく、デンプン の消化によって生ずるグルコースやマルトースがセルロースの利用を抑制するという，基質利用の優先 性によるもの之推測された，一方，低レベルのデンプンまたはグルコースの場合は，グルコースやマル トースが速やかに消費されるたかセルロース利用が㧕制を受ける時間が少なく，むしろ易発酵性基質の 利用によりセルロース分解菌か増加するため，また恐らく他菌の増殖が好ましい影響を与えるために， 全期間におけるセルロース分解が增加するものと考えられた，一日に 2 回デンプンを給与した場合は，

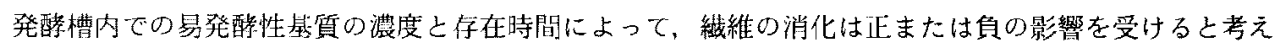
られた。

日畜会報，64(11)：1070-1078, 1993 